\title{
The Nature and Legal Effects of Shareholders Agreements in the Czech and Slovak Private Law and its Interpretation
}

\author{
Sandra Brožová, Ing. \\ University of Economics in Prague, the Czech Republic
}

\begin{abstract}
The aim of this article is to capture the nature of interpretation of the commercial and legal phenomenon called shareholders' agreements. It discusses particularly judicial interpretation in several European jurisdictions. The following research questions are posed: Are the shareholders agreements capable of inducing the informal change of corporate statutes? Is the prevailing character of the shareholders agreements contractual or corporate? Is it possible to conclude shareholders agreements dealing with voting rights exercise in the course of corporate management? The main focus is to give an overview of the prevailing trends of interpretation against the backdrop of comparison of the Czech and Slovak legal regulation with western Europe's approach. The results showed that the explicate legal definition and regulation of shareholders agreements in Slovakia on the level of generally binding source of law is rather unique in Europe and that the broad acceptance of shareholders agreement in some western European countries (e.g. Germany, Austria and Netherlands) is very liberal and more extensive that their usual perception in the Czech Republic and in Slovakia.
\end{abstract}

Keywords: Shareholders agreements, Statute, Corporation, Rules of interpretation

\section{Introduction}

Shareholders agreements (alternatively extra-statutory agreements or side letters, often abbreviated as "SHA") represent a significant expression of autonomy of will and contractual freedom which are the two key values of private law in democratic society and free market economy. In the corporate world, we should always remember that the corporation represents a distinct legal personality, a newly created and formally independent subject of law that needs to be treated differently from its shareholders, who act as owners, as well as management professionals who conduct decision making and 
controlling tasks over the business activities of the company (Bite, Jakuntaviciute, 2014, p. 109; Aliaj, 2014, p. 158).

We can observe the increasing importance of these "side" agreements in the today's situation when the corporate law regulation is getting more and more extensive, complicate and deep-rooted, it includes imperative norms where no distinct regulation between private parties is allowed.

In terms of commercial and corporate legal regulation, these extra statutory agreements are among the most interesting aspects of interpretation of articles of association and statutes of limited liability companies and jointstock corporations. Their economic sense is to reach mutual understanding among particular stakeholders and therefore to create reasonable expectations regarding the future property and financial relations of shareholders to the company, e.g. in case of liquidation, winding-up, bankruptcy or insolvency proceedings.

According to Stedman and Jones (1990, p. 53), we can define shareholders agreement as "an agreed superstructure to supplement and prevail over the articles which form the basic infrastructure." Shareholders agreements are, as in Duffy (2008, p. 1) conceptualized as contracts from the legal point of view and are understood as "a reassertion of contractualism." They present a useful tool bringing some additional flexibility to company's legal affairs regulation. It is not surprising that this instrument is used more and more often in today's business life. Nowadays the respect for contractual freedom is widely prevailing in market economies, while there are also older, classical views criticizing the existence of extra-statutory agreements for their lack of transparency, such as Schmitthoff (1970, p. 1).

Elson (1967, p. 449) understands the classical purpose of shareholders agreements "to eliminate the tyranny of the majority." Clearly, we understand side letters as an instrument to protect individual shareholders' legal interests. Nevertheless, they can be applied for other various purposes. Just to name some of them (Duffy, 2008, p. 4): to establish or maintain balance of power among the company's founders, directors or shareholders, to establish, maintain or amend the organizational structure of the company, to formulate priorities and business policy, to set rules for future cases, such as liquidation of the company or succession in case of death of shareholders - natural persons, to divide and elucidate roles in management and decision making, to attenuate or enforce mechanisms of internal control, to confer additional rights for shareholders that would not be legally enforceable without special concluded arrangement, to confer veto rights, to solve difficult communication situations and resolve disputes, to strengthen protection of special interests (e.g. additional rights for minority stakeholders or confidentiality of information that would otherwise be published under the rules of transparency). 
This paper is aimed to discuss and answer several research questions:

- Q1: Are the shareholders agreements capable of inducing the informal change of corporate statutes?

- Q2: Is the prevailing character of the shareholders agreements "contractual" or "corporate"?

- Q3: Is it possible to conclude shareholders agreements dealing with voting rights exercise in the course of corporate management?

\section{The nature and legal effects of shareholders agreements}

We can divide the legal rules regulating corporations into two layers: there are some core norms represented by generally binding laws and some additional, not mandatory rules that can be legally disregarded or abrogated by different deriving regulation for particular cases (Ronovská, Havel, 2016). The core norms are contained in laws and in the parts of statutes that are prescribed by law, while the others can be found in non-mandatory parts of statutes and in shareholders agreements, concluded voluntarily by shareholders among themselves and/or with the corporation as a legal person. The statutes of corporations have indeed their contractual basis, they are concluded as a contract among all the founding shareholders of the newly established corporations. The business corporation can be together with traditionally Coase (1937) and more recently also Jensen and Meckling (1976) famously understood as a "nexus of obligations." In the U.S. law, according to the Cornell University School of Law, we learn simply that "...a corporation is a legal entity created through the laws of its state of incorporation." Also in the Czech law, it is usual that the corporation is founded by adopting its statute or concluding another contract, as it is stipulated by the wording of Section 125, the new Czech Civil Code, No. 89/2012 Coll.

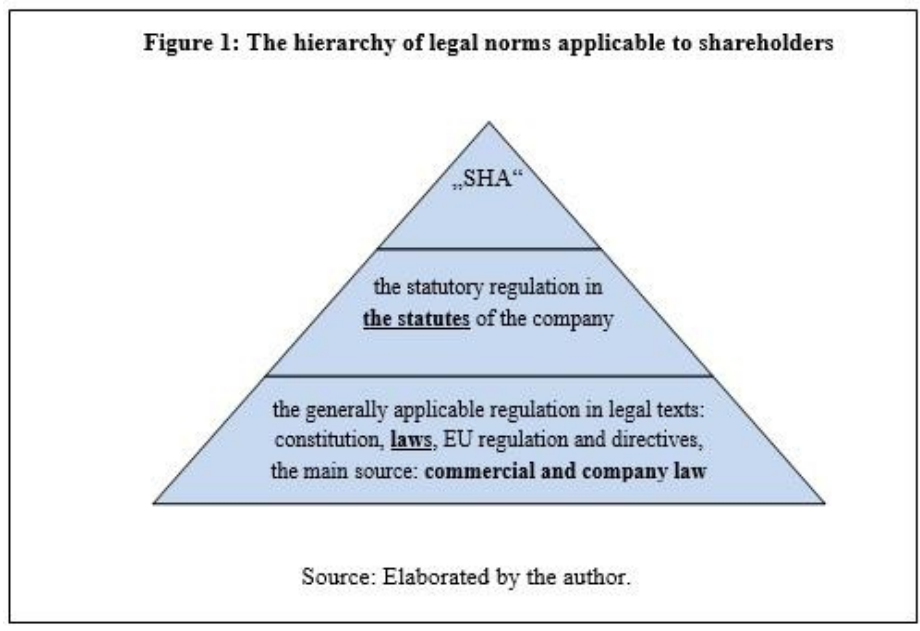


In other words, shareholders are entitled to reach an agreement within the general assembly meeting that derives from the rules written in the statute. As recognized in the judgment of the Supreme Court of the Czech Republic, from 2009, usually such a shareholders agreement is accepted as a "one-time" change, a particular derivation, while it is not universally accepted as a valid change of the statutory text having effect on future times.

The legal standing of shareholders as subjects capable of influencing the rules governing corporation and its internal and external relations is getting stronger nowadays. In the EU, the shareholders have recently gained new rights on information about the business developments and other important features of their company, due to the Directive (EU) 2017/828 of the European Parliament and of the Council of 17 May 2017 amending Directive 2007/36/EC as regards the encouragement of long-term shareholder engagement, which is now since 2019 in its full application.

Shareholder agreements, "extra-statutory agreements" or "side letters" are a legal institute that strongly reflects the contractual nature of a corporation's statutes. Shareholders agreements, being a contract by their nature, do belong to the law of contracts inherently, but (with regards to their substantive content) with significant overlaps into corporate law. They are governed by the general rules on the formal requirements and validity conditions of the legal action as any other contract. Their contractual nature is reflected also when it comes to undue execution or breach of an agreement by one of its parties. The other affected parties may require compensation, liabilities or termination of the whole contract, depending on the particular national law regulation.

Some large companies may develop their "boilerplate" sample texts for those agreements reusable for multiple consecutive occasions, while the precise form of a shareholders agreement is not legally prescribed and therefore can be drafted in any way that expresses the common will of the involved persons in a well understandable and unequivocal manner.

It is important to mention that the shareholders agreements have some limitations. Under common law system, these extra-statutory agreements cannot deprive the corporation of the competence to change its own statute, even if the corporation itself would be party of such an agreement. This was expressed by the decision of the House of Lords in the UK, Russel v. Northern Bank Development Corporation Ltd. Similarly in Australia, any shareholder agreement cannot override statutory contract (Duffy, 2008, p. 8).

The contractual substance of shareholder agreements is also reflected in the sphere of private international law, as the choice of law can be applied to them under Article 3 (1) of the Rome I Regulation. In case the choice of law has not been made, it is suitable to choose, under Article 4 (4) of this Regulation, the personal status of a commercial corporation as the law with 
which the contract is most closely connected (Bříza, 2017, p. 108). Although shareholder agreements materially concern corporations (they could not be created without a corporation, otherwise they would not make sense), they do not fall within the exception written in Article 1 (2) letter f) that the Rome I Regulation does not apply to matters governed by company law. They are not a basic, obligatory instrument of corporate law, but, on the contrary, an optional manifestation of will beyond the core structure of any corporation.

Extra-statutory agreements constitute bilateral or multilateral legal action taken outside the statutes, although they address issues that might or may not be included in the statutes themselves, but shareholders have expressed their will to use less formal and more flexible framework of the shareholders agreement. These agreements have practical significance mostly in large capital companies with a large number of shareholders, i. e. predominantly in a public joint stock company and also in bigger private limited liability companies.

Another very important reason to apply shareholders agreement in the todays' corporate reality is the fact the articles of association and the statutes are compulsorily published in the collection of documents in commercial register, while informal agreements, although in writing, are not subject to the statutory disclosure obligation and thus allow shareholders to set their mutual future legal relationships in a binding manner without "informing" its creditors or other entities through commercial register. Perhaps this is why shareholders' agreements are not very often even reflected in decision-making activities of top civil and commercial courts.

Amendments to shareholder agreements do not require the form of an authentic instrument (notarial deed) neither the decision of a general meeting or of all shareholders. Obviously, the transfer of shares does not automatically cause transfer rights and liabilities from shareholder agreement, since it only binds its contracting parties. To transfer rights and obligations, it would be necessary to change subjects of the agreement. The eventual recovery of liabilities from these agreements can also only take place on a contractual level, e.g. by arranging a contractual penalty. Shareholders agreements in general do not have to necessarily be concluded in a written form. On the other hand, we can only recommend written form in case of future disputes and therefore easier proof of evidence. However, this condition of written form is explicitly set in some national legal orders, e.g. in Slovakia.

Shareholders agreements are a legal tool for articulating the various interests of associates and shareholders, which need to be counterbalanced by interpretation, so that partial agreements do not become manifestly contrary to the general interests of society. According to the Section 212 (2) of the Czech Civil Code, "if a member of a private corporation abuses his right to vote to the detriment of the whole, a court shall, on the application of the person who 
has demonstrated legal interest, decide that the vote of that member is disregarded in a particular case. This right is extinguished, unless the application is filed within three months from the day on which the right to vote was abused."

A public joint-stock company is mostly a large company where different interests of shareholders and its groups are present. Therefore, partial agreements are an appropriate tool for their enforcement, because finding a generally acceptable compromise is sometimes nearly impossible. Nevertheless, it is necessary to seek such an arrangement that the implementation of contractual freedom does not interfere with the fundamental issues of the organization of society and the mandatory provisions of the law.

Figure 2: The most important issues being incorporated into the SHA

\begin{tabular}{|c|ll|}
\hline $\begin{array}{c}\text { related to the } \\
\text { company's structure } \\
\text { and legal } \\
\text { consequences for the } \\
\text { company }\end{array}$ & $\bullet$ & $\begin{array}{l}\text { the amendment of statutes } \\
\text { the change of the share capital and contributions } \\
\text { conditions of transfer of shares in favor of third persons }\end{array}$ \\
\hline $\begin{array}{c}\text { related to the legal } \\
\text { standing of the } \\
\text { shareholders and } \\
\text { their property rights }\end{array}$ & $\bullet$ & $\begin{array}{l}\text { the voting on the shareholders meeting } \\
\text { support for candidates to the board of directors or other } \\
\text { organ } \\
\text { the purchase or sale of the company's undertaking }\end{array}$ \\
\hline
\end{tabular}

Source: Csach, 2017

Although shareholders agreement does not have to be written in all the countries, a manifested agreement is needed, while de facto acting in concert or having a shared interest among the partners is not sufficient, according to Csach $(2017$, p. 3). In other words, there are only shareholder agreements and there is no possibility of taking into account the practice of shareholders by analogy. On the other hand, in public international law, where the international treaty is the most important source of law today, the codified legal rules are different. The Vienna Convention on the Law of Treaties of 23 May 1969, which comprehensively regulates the process of concluding and applying international treaties, explicitly states in its Article 31 (3) on Interpretation of treaties that: "... shall be taken into account, together with the context: (a) Any subsequent agreement between the parties regarding the interpretation of the treaty or the application of its provisions; (b) Any subsequent practice in the application of the treaty which establishes the agreement of the parties regarding its interpretation;..."

The subsequent agreements and subsequent practice are both widely used in the current reality of international treaty law, as demonstrated by recent research by the UN International Law Commission, elaborated in a comprehensive Analytical Guide published in December 2018. In the public international law system, the large multilateral treaties where many States are 
parties represent a very significant feature, while most of these treaties lack a purely obligatory character, because they are negotiated and ratified with intention of general norm-creation.

\section{The private law in the Czech and Slovak Republics}

This contribution is intended particularly to compare the legal regulation of shareholders agreement and its interpretation in the Czech Republic and in Slovakia.

To present the current state of affairs, let us briefly revise the recent historical development: After the dissolution of the Czechoslovak federation on 31 December 1992, the two successor republics decided to overtake the previous federal legal order that was at that time equally valid for both nations. Since the establishment of two independent republics, each of them developed its legal system with improvements, amendments and removal of previously federative laws on its own. Therefore, it is not unusual that originally the same legal text is currently in force in both republics but with some amendments that differ in comparison of the Czech and Slovak version. Another possibility is that one of the successor states continues to use the predecessor's federative laws with necessary updates while the other one has developed completely new set of regulations.

The private law in the Czech Republic was recently principally recodified - the new Civil Code, containing also unified law of contracts relevant also for business, commerce and foreign trade use, and the new Commercial Corporations Act, were adopted in 2012 and are in force since January 1, 2014. However, some established principles continue to be shared with the previous legal regulation containing separate Commercial Code adopted in 1991 and establishing special regulation of commercial contacts within corporate and business relations. The Commercial Code was annulled and replaced to a significant extent by the comprehensive new Civil Code. On the other hand, in Slovakia, this Commercial Code that was adopted at the beginning of economic transformation in 1991 is still valid and has undergone some development that did not happen in the Czech Republic where already the recodified private law is in force. At the beginning of this year 2019, it has been exactly 5 years of our new principle private law regulation and its practical implementation.

When it comes to interpretation, the core value of private contract law in the Czech Republic and other democratic states is the autonomy of will, accompanied with the liberty of contract. This means that it is possible to create every extra-statutory particular and deriving regulation that is not contrary to generally binding law or its leading principles. In the Czech law, we can find these leading interpretative principles codified in the introductive part of the new Civil Code, No. 89/2012 Coll., in force since January 1, 2014. 
We can truly understand this freedom as a cornerstone of modern democratic private law systems.

The Slovak law regulates shareholder agreements explicitly as of 1 January 2017, when this was incorporated into the Commercial Code, Act No. 513/1991 Coll. A new Section 66c regulating "agreements between shareholders" was inserted. The agreement must be in writing and must govern the mutual rights and obligations of shareholders arising from their participation in corporation. Furthermore, the provision contains an illustrative list of possible issues covered by these agreements. It is expressly stated that the contradiction of the decision of the company body with shareholder agreement does not invalidate such a decision. However, a contrary opinion was expressed earlier by German and Austrian courts: according to them, shareholders agreement can induce invalidity of the decision taken by corporation's organ. This appeared in the judgment of the German Supreme Court from 1983, and similarly in the judgement of the Austrian Supreme Court from 1999.

Table 1: The timeframe of the company law in the Czech and Slovak Republics

\begin{tabular}{|c|c|c|c|}
\hline 1 January 1992 & 1 January 1993 & 1 January 2014 & 1 January 2017 \\
\hline \multirow[t]{2}{*}{$\begin{array}{l}\frac{\text { The Commercial }}{\text { Code (Act No. }} \\
\frac{513 / 1991) \text { enters }}{\text { into force in }} \\
\text { Czechoslovakia at } \\
\text { the beginning of } \\
\text { economic and } \\
\text { political } \\
\text { transformation } \\
\text { towards capitalism } \\
\text { and free market. }\end{array}$} & $\begin{array}{c}\text { The end of federal } \\
\frac{\text { Czechoslovakia - }}{\text { the newly }} \\
\text { established Czech } \\
\text { and Slovak } \\
\text { republics emerge } \\
\text { while } \\
\text { simultaneously } \\
\text { adopting all the } \\
\text { previous federal } \\
\text { legislation. }\end{array}$ & $\begin{array}{l}\text { In the Czech } \\
\text { Republic, the } \\
\text { overall } \\
\text { recodification of the } \\
\text { private law came } \\
\text { into effect. New } \\
\frac{\text { Civil Code replaces }}{\text { the repealed old }} \\
\frac{\text { Civil Code and also }}{\text { the Commercial }} \\
\underline{\text { Code. }}\end{array}$ & $\begin{array}{l}\text { In Slovakia, an } \\
\text { amendment of } \\
\text { Commercial Code } \\
\text { brings explicit } \\
\text { definition of } \\
\underline{\text { shareholders }} \\
\text { agreements. }\end{array}$ \\
\hline & & $\begin{array}{l}\text { Both of these } \\
\text { previous private law } \\
\text { codes still stay in } \\
\text { effect in Slovakia. }\end{array}$ & $\begin{array}{l}\text { No explicit } \\
\text { definition of } \\
\text { shareholders } \\
\text { agreement in the } \\
\text { Czech Republic, } \\
\text { only general } \\
\text { legislative } \\
\text { provisions can } \\
\text { andv. }\end{array}$ \\
\hline \multicolumn{2}{|c|}{$\begin{array}{l}\text { the same legislation } \\
\text { in } \mathrm{CZ} \text { and } \mathrm{SK}\end{array}$} & \multicolumn{2}{|c|}{$\begin{array}{l}\text { the differing legislation } \\
\text { in } \mathrm{CZ} \text { and } \mathrm{SK} \\
\end{array}$} \\
\hline
\end{tabular}

Source: Elaborated by the author on the base of laws published in the official sources.

The legislator thus resolves a possible contradiction between such dual manifestations of will with different content affecting the business 
corporation. A formalized decision of a company body takes precedence over an "informal" shareholder agreement that is legally binding only between its parties. Therefore, we can conclude that even a possible discrepancy between the shareholder agreement and the text of the articles of association cannot cause the articles of association to be invalidated, but such a situation should be interpreted as a derogation that binds only the parties to the agreement as a contractual obligation.

Further details of shareholder agreements, as far as issues of transfer of shares are concerned, are governed by the Slovak (originally Czechoslovak) Commercial Code in Sections 202w to 202z. Some shareholder agreements are in Slovakia explicitly prohibited under Section 186a of the Commercial Code. These are mainly agreements binding shareholders on certain manner of exercising voting rights, incl. compliance with instructions from company bodies and cases with prior arranged compensation. This explicit ban has been abolished in the Czech Republic with recodification, but in the context of a public joint-stock company, we must not forget Section 244 (2) of the Commercial Corporations Act, according to which "... any legal act aimed at obtaining an unjust advantage in favor of a shareholder at the expense of the company or other shareholders shall be disregarded, unless provided otherwise in this Act or unless it would be harmful to any third person who relied in good faith on such legal act."

We find it useful that the Slovak legislature has explicitly defined the essential elements of shareholder agreements. The contemporary Czech private law, on the other hand, neither explicitly regulates nor prohibits shareholder agreements. The same is true in some other European legal systems, such as the English and German ones. Under English law, the corporate law is codified by the Companies Act from 2006. In German law, there are specific laws for each type of business corporations, such as the Limited Liability Company Act or the Act on Public Joint Stock Company. In Section 136 (2) of the German Public Joint Stock Company Act, there is a prohibition of agreements about the manner in which voting rights are exercised, about binding shareholders to vote in the opinion of the company, board of directors or supervisory board. Such agreements would be invalid.

In the light of the autonomy of the expressed will and contractual freedom, the German Supreme Court in 2010 concluded that a decision of a general meeting of a company which does not meet the requirements for its validity prescribed by law or the articles of association may be regarded as a manifested agreement of the shareholders. However, Csach (2017, p. 31) notes that such contractual freedom cannot be understood as absolute and it is not possible to automatically consider any invalid decision of a general meeting to be a shareholder agreement that itself has certain legal consequences. 
The above ban on some kind of shareholder agreements, how it works in Germany, in Slovakia and how it used to work also in our country before the recodification, is not universally shared in other European legal systems. E.g. according to the Dutch case-law, shareholder agreements on voting rights are valid (Van Ween, 2017, p. 229). On the other hand, the subsequent vote in conflict with the previously concluded agreement cannot invalidate the vote the vote is valid for the company, even if it has departed from the previously concluded agreement (of course, this does not affect any individual claims for damages). In this context, we can remind the previously mentioned fact that the new Czech Civil Code allows under Section 212 (2) to disregard the vote resulting from the misuse of voting rights to the detriment of the corporation as a whole (and only on the basis of a court decision at the request of the interested party filed in three-months period).

Today's commercial law respects the expressed will of the shareholders and considers the agreement of all shareholders as a materially comparable expression of will as if it were a decision of the shareholders at the general meeting. This also applies to changes to the articles of association, i. e. the range of issues that the statute deals with in some way, but all the shareholders have agreed on a preferred other arrangement when concluding the informal extra-statutory agreement. This statement is supported by the judicial interpretation by the Czech Supreme Court (2007).

In other words, a valid shareholder agreement of all shareholders may be contrary to the company's statutes, but not contrary to the generally binding (both national and European) law. The same conclusion, elaborated by Šuleková (2017, p. 255 - 256) regarding the admissibility of amendments to the articles of association by agreement of all shareholders is directed by the English legislation. German case law (the judgments of the German Supreme Court from 1980s) even allows for a possible relative nullity of a general meeting resolution if it is contrary to extra-statutory agreement adopted by all the shareholders.

\section{The difference between statutory and extra-statutory regulation}

The company's statutes and shareholders agreements form a set of rules that relate to the functioning of a commercial corporation and constitutes its legal background, which should be considered as a whole set of rules and courts should avoid artificial distinction when conducting interpretation, as Royal Court in London stated in 2013 in case McKillen v Misland (Cyprus) Investments Ltd \& Ors.

The difference between the amendment of the statute and the acceptance of the agreement of all shareholders that have divergent content from the wording of the statute is thus mainly due to the variations in the formal process in which the concerned legal act is formed. If we applied a 
logical interpretation with respect to systematic organization of corporate law as a whole, we would identify significant changes in content: extra-statutory agreements obviously cannot regulate the principal, fundamental characteristics of a commercial company such as its business name, registered office, share capital, etc. Of course, the legal effects vis-à-vis third parties are also different - while statutes bind all shareholders and the company itself and members of its bodies, shareholder agreements bring contractual obligation only to entities that have concluded this agreement with each other.

For instance, as the Czech Supreme Court stated in 2005, by way of a secondary arrangement, a pre-emptive purchase right may be established for future cases of selling shares, even if the objective law does not regulate such an institute. In terms of interpretation, according to Ronovská and Havel (2016), it is logical that statutes require a higher degree of objectivity of interpretation than its subsidiary agreement, where subjective interpretation may outweigh its wider personal scope.

Nevertheless, the Dutch law attaches great importance to shareholder agreements and even attributes to them the so-called "corporate effect", i. e. that these agreements also have an effect on the company itself, and moreover, on other people who are involved in the organization of the corporation and who also have to follow these agreements. This opinion was found in the Dutch Supreme Court's judgments from 1960s and also from recent years. Under the British law, according to the House of Lords decision in Russel $v$. Northern Bank Development Corporation Ltd., the shareholders can agree about how they will exercise their voting rights in the future. This we can understand as a wide delimitation of allowed material scope of extra-statutory parallel regulation.

\section{Modelling}

According to our research, it is not possible to employ quantitative research methods on the issue of shareholders agreements because as mentioned above these side agreements are not usually published (although some exceptions exist, e. g. with regards to companies under state and public ownership being under particular duties to ensure general transparency in relation to public budgets spending). The lack of necessity to publish the concluded agreement, being a commercial contract with contractual binding force, is perceived as a great advantage for parties not willing to let their concluded agreement become known by creditors, business partners or wider public. However, this causes the impossibility to capture exact numbers of these agreements being concluded in certain times and jurisdictions. As a result, we therefore cannot now measure their economic effectivity and impact on business environment by quantitative models. 
This is quite different from the structure and proportion of ownership of the companies with shares listed on stock exchange. The information on ownership structure is in the majority of jurisdictions obligatory to be published and the same applies for the economic performance of the company's business. Therefore, it enables researchers to develop econometric models evaluating company's economic effectivity in dependence on ownership structure (Isik - Soykan, 2013).

The presence of large shareholder, i. e. one owner with influence over the vast majority of the company's shares, proved to have positive impact on business performance, because this large shareholder is directly interested and motivated in raising the value and economic performance of the firm forming part of his assets (Isik - Soykan, 2013, p. 34). The participation of shareholders and institutional investors can be measured also in relation to their impact on corporate governance (Huang - Xie, 2016).

The structured results of our qualitative research, based on three concrete research questions, are presented in this table:

Table 2: The nature and legal effects of shareholders agreements

\begin{tabular}{|c|c|c|c|}
\hline Country & $\begin{array}{l}\text { Q1: the capability of } \\
\text { changing the } \\
\text { corporate statutes }\end{array}$ & $\begin{array}{l}\text { Q2: the prevailing } \\
\text { nature of SHA }\end{array}$ & $\begin{array}{l}\text { Q3: the legality of } \\
\text { voting rights to be } \\
\text { regulated by SHA }\end{array}$ \\
\hline the Czech Republic & $\begin{array}{c}\text { accepted (as a unique } \\
\text { derogation) }\end{array}$ & $\begin{array}{c}\text { contractual } \rightarrow \text { it } \\
\text { cannot cause invali- } \\
\text { dity of corporate } \\
\text { body decision }\end{array}$ & $\begin{array}{l}\text { previously banned } \\
\text { by law }\end{array}$ \\
\hline Slovakia & accepted & $\begin{array}{l}\text { contractual } \rightarrow \text { it } \\
\text { cannot cause invali- } \\
\text { dity of corporate } \\
\text { body decision }\end{array}$ & banned by law \\
\hline Germany & accepted & $\begin{array}{c}\text { corporate } \rightarrow \text { it can } \\
\text { cause invalidity of } \\
\text { corporate body } \\
\text { decision }\end{array}$ & banned by law \\
\hline Austria & accepted & $\begin{array}{c}\text { corporate } \rightarrow \text { it can } \\
\text { cause invalidity of } \\
\text { corporate body } \\
\text { decision }\end{array}$ & N/A \\
\hline the Netherlands & accepted & corporate & accepted \\
\hline $\begin{array}{l}\text { the United } \\
\text { Kingdom }\end{array}$ & $\begin{array}{l}\text { accepted (but it cannot } \\
\text { deprive the corporation } \\
\text { from the power to } \\
\text { change its statutes) }\end{array}$ & corporate & accepted \\
\hline RESULTS & $\begin{array}{c}\text { the interpretation is } \\
\text { the same }\end{array}$ & $\begin{array}{c}\text { the interpretation } \\
\text { differs }\end{array}$ & $\begin{array}{c}\text { the interpretation } \\
\text { differs }\end{array}$ \\
\hline
\end{tabular}

Source: Elaborated by the author. 


\section{Conclusion}

In summary, shareholder agreements are respected as a form of expression of the identical free and autonomous will of the shareholders to the extent that they can validly replace the form of expression of will required by legal order to amend the statutes. It is also important to stress that the extrastatutory regulation can only be based on an agreement, not any concerting and settled shareholder practice, which has itself no legally relevant effects. We showed that the Slovak legislation is particularly interesting and inspiring in that it explicitly defines the shareholder agreement and covers its essential requirements, especially the written form which is not required in some other countries, e.g. common law jurisdictions.

In the Central European area (in the German, Slovak and, until recently, Czech legislation), it is usual to define the prohibition of certain types of agreements that oblige shareholders to exercise their voting rights in a certain manner, while in some liberal Western European countries, such the United Kingdom or Netherlands, voting shareholder agreements are also valid - their sphere of applicability is even wider. One of the strongest proofs of the significance of the shareholders agreements is the invalidity of the shareholders meeting resolution if it is contrary to the previous shareholders agreement.

Our study led to the comparison of several European jurisdictions with diverse social, political and philosophical backgrounds that now share the internal market of the EU. We evidenced the differing approaches towards the issue of shareholders agreements. The first research question turned the same results, in sense that in all the analyzed countries the shareholders agreements are able to change the statutes. On the other hand, the other two analyzed issues showed divergent interpretation. In Western Europe, it is common to perceive any "side" agreement as a tool not only to amend the statute but even to exercise voting rights in fact, while in Central Europe, the mainstream is not to allow the "side" agreement cause the invalidity of the corporate organ's resolution, therefore assigning only a limited validity for such and informally expressed common will of private subjects.

\section{References:}

1. Aliaj, E. (2014) The principle of shareholders' limited liability and its exception in Albanian company law. European Scientific Journal. Vol. 10, No. 22, 2014, 158-167.

2. Bite, V. - Jakuntaviciute, G. (2014) Is the limited liability doctrine applicable to company directors? European Scientific Journal. Vol.10, No.16, 2014, 109 - 128.

3. Bř́zza, P. (2017) Akcionářské dohody a smlouvy o převodu podílu z pohledu mezinárodního práva soukromého. [Shareholders agreements 
and contracts on the transfer of shares from the private international law viewpoint.] In Csach, K. and Havel, B. (Eds): Akcionářské dohody [Shareholders agreements]. Wolters Kluwer: Praha, 103 - 130.

4. Coase, R. H. (1937) The Nature of the Firm, Economica, 4(16), 386 405.

5. Csach, K. (2017) Dohody medzi spoločníkmi (akcionárske dohody). [Shareholders agreements]. In Csach, K. and Havel, B. (Eds): Akcionářské dohody. [Shareholders agreements]. Wolters Kluwer: Praha, 3- 48.

6. Duffy, M. (2008) Shareholders Agreements and Shareholders' Remedies Contract Versus Statute? Bond Law Review, 20(2), 1-26.

7. Elson, A. (1967) Shareholders Agreements: A Shield for Minority Shareholders of Close Corporations. Business Lawyer. 22(2), 449-457.

8. Huang, S. - Xie, R. (2016) Impact of Shareholder Activism on Corporate Governance in China: Evidence from companies listed on the Shenzhen Stock Exchange "A" Shares. European Scientific Journal. Vol. 12, No. 1, 2016, $114-128$.

9. Isik, O. - Soykan, M. E. (2013) Large shareholders and firm performance: Evidence from Turkey. European Scientific Journal. Vol. 9. No. 25, 2013, $23-37$.

10. Jensen, M. - Meckling, W. (1976) Theory of the Firm: Managerial Behavior, Agency Costs and Ownership Structure. Journal of Financial Economics, 3(4), 305-360.

11. Ronovská, K. - Havel, B. (2016) Povaha a pravidla výkladu (nejen) zakladatelských právních jednání soukromých korporací. [The nature and interpretation rules of (not only) constitutive legal acts of private corporations]. Právní rozhledy [Legal Review], (24)18, 611 - 615.

12. Schmitthoff, K. (1970) House of Lords Sanctions Evasions of Companies Act. Journal of Business Law, (1)1, 1970.

13. Stedman, G. - Jones, J. (1990) Shareholders Agreements, 2nd edition, Longman.

14. Šuleková, Ž. Akcionárske dohody v anglickom práve. . [Shareholders agreements in English Law.] In Csach, K. and Havel, B. (Eds): Akcionářské dohody. [Shareholders agreements] Wolters Kluwer: Praha, $251-264$.

15. Van Ween, W. Akcionárske dohody $\mathrm{v}$ holandskom práve. Vplyv akcionárskych dohôd na správu a riadenie spoločností. [Shareholders agreements in Dutch Law. The influence of shareholders agreeements on the management of corporations.] In CSACH, K. and HAVEL, B. (Eds): Akcionářské dohody. [Shareholders agreements]. Wolters Kluwer: Praha, p. 227 - 249. 


\section{Legal documentation:}

- Czech Republic - Civil Code, No. 89/2012 Coll.

- United Kingdom - Companies Act 2006 [on-line, accessed 2019-0711] <https://www.legislation.gov.uk/ukpga/2006/46/contents>

- Germany - Gesetz betreffend die Gesellschaften mit beschränkter Haftung [on-line, accessed 2019-07-11] <https://www.gesetze-iminternet.de/gmbhg/>

- Germany - Aktiengesetz [on-line] <https://www.gesetze-iminternet.de/aktg/__ 1.html>

- Decision of the House of Lords in the UK, Russel v. Northern Bank Development Corporation Ltd., 1992, No. 1 WLR 588.

- Directive (EU) 2017/828 of the European Parliament and of the Council of 17 May 2017 amending Directive 2007/36/EC as regards the encouragement of long-term shareholder engagement.

- Judgement of the Austrian Supreme Court, August 26, 1999, File No. 20b46/97x.

- Judgment in McKillen v Misland (Cyprus) Investments Ltd \& Ors [2013] EWCA Civ 781 (03 July 2013). [on-line, accessed 2019-07-11] <http://www.bailii.org/ew/cases/EWCA/Civ/2013/781.html >

- Judgment of the Dutch Supreme Court (HR) in Chipshol vs. Landinvest, November 29, 1996, ECLI: NL: HR: 1996: ZC2211

- Judgment of the Dutch Supreme Court (HR) in Roovers / Cancun Holding I, April 4, 2014, ECLI: NL: HR: 2014: 797.

- Judgment of the German Supreme Court, January 20, 1983, File No. II ZR 243/81,

- Judgment of the German Supreme Court, January 20, 1983, File No. 243/81.

- Judgment of the German Supreme Court, March 15, 2010, File No. II ZR 4/09.

- Judgment of the German Supreme Court, October 27, 1986, File No. II ZR 240/85

- Judgment of the Supreme Court of the Czech Republic, April 22, 2009, File No. 29 Cdo 2254/2007.

- Judgment of the Supreme Court of the Czech Republic, December 13, 2005, File No. 29 Odo 1339/2004.

- Judgment of the Supreme Court of the Czech Republic, from April 22, 2009, File No. 29 Cdo 2254/2007.

- Regulation (EC) No 593/2008 of the European Parliament and of the Council of 17 June 2008 on the law applicable to contractual obligations (Rome I Regulation). 


\section{Electronic sources:}

- Cornell University - Legal Information Institute. [on-line, accessed 2019-06-10]

$<$ https://www.law.cornell.edu/wex/corporations >

- United Nations International Law Commission: Analytical Guide to the Work of the International Law Commission. Subsequent agreements and subsequent practice in relation to interpretation of [on-line, accessed 2019-07-11] $\langle\underline{\text { http://legal.un.org/ilc/guide/1_11.shtml }>~}$ 